\title{
Potensi Alga Merah dan Alga Hijau untuk Menghambat Pertumbuhan Bakteri Eschericia coli
}

\author{
KETUT SRIE MARHAENI JULYASIH*), NI PUTU RISTIATI, DAN \\ IDA BAGUS PUTU ARNYANA
}

Jurusan Biologi dan Perikanan Kelautan, Universitas Pendidikan Ganesha

Jl. Udayana No.11, Banyuasri, Kec. Buleleng, Kabupaten Buleleng, 81116 Bali

${ }^{*}$ E-mail: smjulyasih@gmail.com

\begin{abstract}
Potential of Red Algae and Green Algae to Inhibit Escherichia coli Bacteria

Growth. The use of synthetic chemicals as a control for the growth of E. coli bacteria that causes of diarrhea children can cause adverse effects on health, so it needs natural control ingredients that do not cause impacts on human health. One natural controller to inhibit bacterial growth is by utilizing natural sources, including seaweed. The purpose of this study was to examine the potential of seaweed as an anti-bacterial agent of E. coli. The research used seaweed extract of Eucheuma spinosum, Euchuema cottonii, Gracilaria spp., and Caulerpa spp. The test parameters observed were the inhibition zone ( $\mathrm{mm}$ ) of each seaweed extract treatment using a ruler and measured the inhibition zone distance. The results showed that E.cottonii seaweed extract had the highest inhibitory ability with an inhibition zone diameter of $11.1 \mathrm{~mm}$, including the moderately sensitive category, then Caulerpa spp. with a inhibition zone diameter of $10.0 \mathrm{~mm}$, Gracilaria spp has the ability to inhibit E.coli bacteria with a inhibition zone diameter of $6.9 \mathrm{~mm}$, including the insensitive category, and the lowest in seaweed E. spinosum with a inhibition zone diameter of $4.2 \mathrm{~mm}$. including the insensitive category.
\end{abstract}

Keywords: Eschericia coli, Caulerpa spp., Gracilaria spp., Eucheuma spinosum. and Eucheuma cottonii

\section{PENDAHULUAN}

Penggunaan bahan kimia sintetis sebagai pengendali pertumbuhan bakteri dapat menimbulkan dampak yang merugikan bagi kesehatan, sehingga perlu bahan pengendali alami yang tidak menimbulkan dampak bagi kesehatan manusia. Salah satu pengendali bakteri alami adalah dengan memanfaatkan sumber dari alam, diantaranya rumput laut.

Sampai saat ini pengobatan diare dilakukan dengan pengobatan kausatif yaitu bakteri penyebabnya dimatikan dengan bahan antibakteri. Escherichia coli adalah bakteri yang banyak ditemukan di usus besar manusia sebagai flora normal. Penderita diare 
KETUT SRIE MARHAENI JULYASIH. et al. Potensi Alga Merah dan Alga Hijau untuk...

banyak menggunakan obat-obatan yang berasal dari bahan kimia dan tanaman herbal, tetapi masih belum ada penelitian yang menjadikansalah satu sumber hayati laut seperti rumput laut untuk dijadikan salah satu alternatif pengobatan diare (Bachtiar et al., 2012).

Pemanfaatan rumput laut dalam bidang farmasi selama ini masih terbatas, sedangkan potensi rumput laut di Indonesia sangat besar untuk dikembangkan sebagai bahan baku obat. Bakteri patogen yang telah resisten terhadap antibiotika ampisilin, kotrimoxasol, dan tetrasiklin, sehingga perlu dilakukan pengujian beberapa jenis rumput laut dalam menghambat pertumbuhan bakteri E. coli.

Tujuan penelitian ini adalah menguji aktivitas anti bakteri alga hijau dan merah dari jenis Caulerpa spp., Gracilaria spp., Eucheuma spinosum. dan Eucheuma cottonii terhadap pertumbuhan bakteri E.coli.

\section{BAHAN DAN METODE}

\section{Pengambilan sampel dan Persiapan}

\section{Ekstrak Rumput Laut}

Rumput laut jenis Caulerpa spp., Gracilaria spp., E.spinosum dan E. cottonii dicuci bersih dan dijemur sampai kering. Rumput laut yang telah kering dihancurkan dengan alat blender, selanjutnya dilakukan proses maserasi selama 24 jam dalam pelarut ethanol $96 \%$, kemudian disaring dengan menggunakan kertas saring Whatman. Ekstrak yang diperoleh dilakukan proses pemisahan antara ethanol dengan rumput laut menggunakan alat vacum evaporator pada suhu $49-50^{0} \mathrm{C}$ sampai semua pelarut menguap, sehingga menghasilkan ekstrak kasar (crude extract). Ekstrak kasar rumput laut selanjutnya siap diuji potensinya sebagai antibakteri.

\section{Uji Ekstrak Rumput Laut Terhadap E.coli}

Media pembenihan NA dibuat dengan cara melarutkan 23 gram NA ke dalam $1 \mathrm{~L}$ aquadest kemudian dipanaskan hingga larut. Media NA $20 \mathrm{ml}$ yang masih cair diisi suspensi spora bakteri uji sebanyak $40 \mu 1$. Setelah beku dibuat lubang dengan cork borer $\emptyset 5 \mathrm{~mm}$ dan selanjutnya lubang sumur diisi ekstrak rumput laut sebanyak 20 $\mathrm{mg} / \mathrm{ml}$. Bakteri E.coli diperoleh dari Laboratorium Teknologi Pangan Universitas Udayana.

Parameter uji yang diamati adalah diameter zona hambat $(\mathrm{mm})$ dari masingmasing perlakuan ekstrak rumput laut dengan menggunakan penggaris atau jangka sorong dan diukur jarak zona hambat (Bachtiar et al.,2012). Daerah hambatan pertumbuhan bakteri secara umum mengacu pada standar umum antibiotika untuk E.coli yaitu amphicillin dengan range $<11 \mathrm{~mm}$ tidak 
peka, 12-13 mm cukup peka dan > $13 \mathrm{~mm}$ sangat peka (Rajasulochana et al., 2010).

\section{HASIL DAN PEMBAHASAN}

Hasil penelitian daya hambat ekstrak rumput laut terhadap pertumbuhan bakteri E.coli diperoleh hasil seperti disajikan pada Gambar 1.

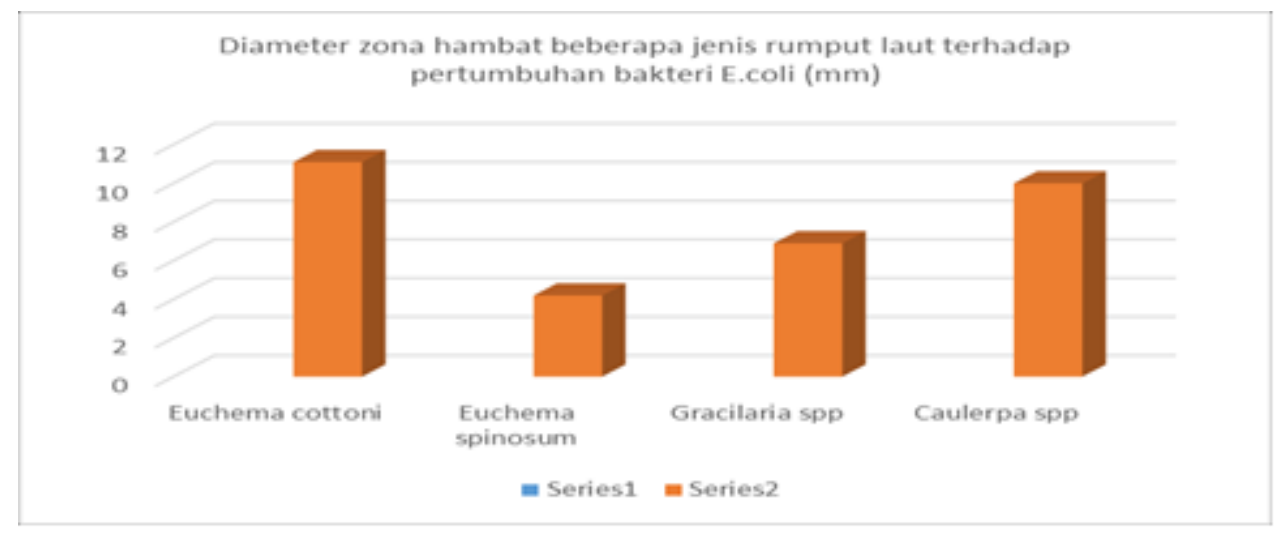

Gambar 1. Diameter zona hambat beberapa jenis rumput laut terhadap pertumbuhan bakteri E.coli

Potensi penghambatan rumput laut fungsi membran sitoplasm (Yunus et al., terhadap bakteri E.coli yang paling tinggi 2009).

terdapat pada rumput laut $E$. cottonii, dengan diameter zona hambat 11,1 mm Caulerpa spp, 10,0 mm, kemudian Gracilaria spp., dengan diameter zona hambat $6,9 \mathrm{~mm}$, dan terendah pada E.spinosum dengan diameter zona hambat 4,2 $\mathrm{mm}$. Hal ini kemungkinan disebabkan karena adanya senyawa fenol dan turunannya (flavonoid) yang terkandung pada tiap jenis rumput laut dan juga kandungan senyawa tannin pada E cottoni, Gracilaria spp., dan Caulerpa spp.. Senyawa fenol dan turunannya (flavonoid) merupakan salah satu anti bakteri yang bekerja dengan mengganggu
Adanya senyawa fenol ini dapat menyebabkan pengrusakan pada sitoplasma. Ion $\mathrm{H}$ - dari senyawa fenol dan turunannya akan menyerang gugus polar (gugus fosfat) sehingga molekul fosfolipida pada dinding sel bakteri akan terurai menjadi gliserol, asam karboksilat, dan asam fosfat. Fosfolida tidak mampu mempertahankan bentuk membran sitoplasma. Akibatnya, membran sitoplasma akan bocor dan bakteri akan mengalami hambatan pertumbuhan bahkan kematian. Flavonoid mencegah pembentukan energi pada membran sitoplasma dan menghambat 
KETUT SRIE MARHAENI JULYASIH. et al. Potensi Alga Merah dan Alga Hijau untuk...

motilitas bakteri, yang juga berperan dalam aksi antimikroba (Yunus et al., 2009).

Golongan senyawa alkaloid, flavonoid, steroid/triterpenoid dan tanin yang terdapat pada ekstrak kasar rumput laut diduga aktif sebagai senyawa antijamur dan antibakteri (Wiyanto, 2010). Hal ini juga sesuai dengan Cox et al. (2010), potensi penghambatan sebagai anti mikroba dikarenakan karena kandungan senyawa fenolik, terpenoid, alkaloid, steroid dan flavonoid darirumput laut. Golongan senyawa kimia utama yang mempunyai sifat antibakteri adalah fenol, alkohol, halogen, logam berat, zat warna, deterjen, senyawa kuarter, asam dan basa. Senyawa fenol dapat berinteraksi dengan komponen dinding sel bakteri sehingga mengakibatkan permeabilitas pada sel bakteri dan dapat juga berdifusi kedalam sel sehingga mengakibatkan pertumbuhan bakteri terhambat atau mati, selain itu senyawa ini juga dapat menembus membran dan berinteraksi dengan material genetik sehingga bakteri mengalami mutasi (Siregar, et al.,2012).

Menurut Suryati et al., (2017) keaktifan biologis dari senyawa alkaloid disebabkan karena adanya gugus basa yang mengandung nitrogen. Adanya gugus basa ini apabila mengalami kontak dengan bakteri akan bereaksi dengan senyawasenyawa asam amino yang menyusun dinding sel bakteri dan juga DNA bakteri yang merupakan penyusun utama inti sel yang merupakan pusat pengaturan segala kegiatan sel. Reaksi ini terjadi karena secara kimia suatu senyawa yang bersifat basa akan bereksi dengan senyawa asam dalam hal ini adalah asam amino karena sebagian besar asam amino telah beraksi dengan gugus basa dari senyawa alkaloid. Perubahan susunan asam amino ini jelas akan merubah keseimbangan genetik pada asam DNA sehingga DNA bakteri akan mengalami kerusakan. Kerusakan DNA pada inti sel bakteri akan mendorong terjadinya lisis pada inti sel, sehingga akan terjadi kerusakan sel. Kerusakan sel mengakibatkan sel-sel bakteri tidak mampu melakukan metabolisme sehingga akan mengalami lisis (hancur).

Rumput laut hijau, merah, ataupun coklat merupakan sumber potensial senyawa bioaktif yang sangat bermanfaat bagi pengembangan 1) industri farmasi seperti antibakteri, anti tumor, anti kanker, dan 2) industri agrokimia terutama untuk anti feedant, fungisida, dan herbisida (Siregar et.al., 2012b).

Potensi penghambatan rumput laut terhadap bakteri E.coli kemungkinan karena adanya senyawa fenol dan turunannya (flavonoid) yang terkandung pada tiap jenis 
rumput laut. Senyawa fenol dan turunannya (flavonoid) merupakan salah satu antibakteri yang bekerja dengan mengganggu fungsi membran sitoplasma. Adanya senyawa fenol ini dapat menyebabkan pengrusakan pada sitoplasma. Ion $\mathrm{H}$ - dari senyawa fenol dan turunannya akan menyerang gugus polar (gugus fosfat) sehingga molekul fosfolipida pada dinding sel bakteri akan terurai menjadi gliserol, asam karboksilat, dan asam fosfat (Chalyyn et al., 2017).

Golongan senyawa kimia utama yang mempunyai sifat antibakteri adalah fenol, alkohol, halogen, logam berat, zat warna, deterjen, senyawa kuarter, asam dan basa. Senyawa fenol dapat berinteraksi dengan komponen dinding sel bakteri sehingga mengakibatkan permeabilitas pada sel bakteri dan dapat juga berdifusi kedalam sel sehingga mengakibatkan pertumbuhan bakteri terhambat atau mati, selain itu senyawa ini juga dapat menembus membran dan berinteraksi dengan material genetik sehingga bakteri mengalami mutasi (Siregar, et al., 2012).

Menurut Suryati et al., (2017) keaktifan biologis dari senyawa alkaloid disebabkan karena adanya gugus basa yang mengandung nitrogen. Adanya gugus basa ini apabila mengalami kontak dengan bakteri akan bereaksi dengan senyawasenyawa asam amino yang menyusun dinding sel bakteri dan juga DNA bakteri yang merupakan penyusun utama inti sel yang merupakan pusat pengaturan segala kegiatan sel. Reaksi ini terjadi karena secara kimia suatu senyawa yang bersifat basa akan bereksi dengan senyawa asam dalam hal ini adalah asam amino karena sebagian besar asam amino telah beraksi dengan gugus basa dari senyawa alkaloid. Perubahan susunan asam amino ini jelas akan merubah keseimbangan genetik pada asam DNA sehingga DNA bakteri akan mengalami kerusakan . Kerusakan DNA pada inti sel bakteri akan mendorong terjadinya lisis pada inti sel, sehingga akan terjadi kerusakan sel. Kerusakan sel mengakibatkan sel-sel bakteri tidak mampu melakukan metabolisme sehingga akan mengalami lisis (hancur).

Rumput laut hijau, merah, ataupun coklat merupakan sumber potensial senyawa bioaktif yang sangat bermanfaat bagi pengembangan 1) industri farmasi seperti antibakteri, anti tumor, anti kanker, dan 2) industri agrokimia terutama untuk anti feedant, fungisida, dan herbisida (Siregar et.al., 2012b).

Potensi penghambatan rumput laut terhadap bakteri E.coli kemungkinan karena adanya senyawa fenol dan turunannya (flavonoid) yang terkandung pada tiap jenis 
KETUT SRIE MARHAENI JULYASIH. et al. Potensi Alga Merah dan Alga Hijau untuk...

rumput laut. Senyawa fenol dan turunannya (flavonoid) merupakan salah satu antibakteri yang bekerja dengan mengganggu fungsi membran sitoplasma. Adanya senyawa fenol ini dapat menyebabkan pengrusakan pada sitoplasma. Ion $\mathrm{H}$ - dari senyawa fenol dan turunannya akan menyerang gugus polar (gugus fosfat) sehingga molekul fosfolipida pada dinding sel bakteri akan terurai menjadi gliserol, asam karboksilat, dan asam fosfat (Chalyyn et al., 2017).

Golongan senyawa kimia utama yang mempunyai sifat antibakteri adalah fenol, alkohol, halogen, logam berat, zat warna, deterjen, senyawa kuarter, asam dan basa. Senyawa fenol dapat berinteraksi dengan komponen dinding sel bakteri sehingga mengakibatkan permeabilitas pada sel bakteri dan dapat juga berdifusi kedalam sel sehingga mengakibatkan pertumbuhan bakteri terhambat atau mati, selain itu senyawa ini ini juga dapat menembus membran dan berinteraksi dengan material genetik sehingga bakteri mengalami mutasi (Siregar et al., 2012). Menurut Sartika et al. (2013), ekstrak alga merah Eucheuma cottonii dapat menghambat pertumbuhan bakteri, baik itu bakteri gram negatif maupun gram positif dan bioaktivitas ekstrak alga merah E. cottonii cenderung bersifat bakteriostatik.

\section{SIMPULAN}

Rumput laut $E$ cottonii mempunyai kemampuan penghambatan tertinggi dengan diameter zona hambat $11,1 \mathrm{~mm}$, termasuk kategori cukup peka, kemudian Caulerpa spp. dengan diameter zona hambat $10.0 \mathrm{~mm}$, Gracilaria spp mempunyai kemampuan menghambat bakteri E.coli dengan diameter zona hambat $6,9 \mathrm{~mm}$, termasuk kategori tidak peka, dan terendah pada rumput laut $E$ spinosum dengan diameter zona hambat 4,2 mm termasuk kategori tidak peka.

\section{UCAPAN TERIMA KASIH}

Ucapan terima kasih kami sampaikan kepada Universitas Pendidikan Ganesha yang telah memberikan dana penelitian Fundamental Institusi tahun 2019 melalui Dana DIPA BLU Universitas Pendidikan Ganesha.

\section{DAFTAR PUSTAKA}

Bachtiar, S.Y., W. Tjahyaningsih., dan N.Sianita. 2012. Effect of Algae Brown (Sargassum sp.) Ekstract Againts Bacterial Growth of Escherichia coli. Journal of Marine and Coastal Sciences ,1(1):53-60

Chalyyn, Pakidi dan Hidayat. 2017. Potensi dan Pemanfaatan Bahan aktif Alga Coklat sargassum sp. Octopus Jurnal Ilmu Perikanan. Vol 6 No 1

Cox,S.,Ghanam,N., Gupta,S. 2010. An assesment of the Antioxidant and Antimicrobial activity of six species of 
Edible Irish Seaweeds. International Food Research Journal 17: 205-220 Rajasulochana,P., P. Krishnamoorthy and R.Damotharan. 2013. An Investigation on the Antioxidants, Antifungal and Antibacterial of the Kappaphycus alvarezii.Research Journal of Pharmaceutical, Biological and Chemical Sciences. RJPBCS Volume 4 Issue 1

Sartika , R., Melki dan A I.S. Purwiyanto. 2013. Aktivitas Antibakteri Ekstrak Rumput Laut Eucheuma cottoni terhadap Bakteri Escherichia coli, Staphylococcus aureus, Vibrio cholera dan Salmonella typhosa. Maspari Journal, 2013, 5 (2), 98-103

Siregar, A.F., S. Agus dan P. Delianis. 2012a. Potensi Antijamur dan Antibakteri Ekstrak Rumput Laut terhadap Jamur A. flavus dan Bakteri Pseudomonas aeruginosa.http://ejournals1.undip.ac.id/index.php/jmr. Akses 11 April 2016.

Siregar, A.F., S. Agus dan P. Delianis. 2012b.

Potensi Anti Bakteri Ekstrak Rumput Laut Terhadap Bakteri Penyakit Kulit Pseudomonas aeruginosa, Staphylococcus epidermides, dan Micrococcus luteus. Journal of Marine Research . Volume 1 No 2. Hal 152160.

Suryati, N., E.Bahar., Ilmiati. 2017. Uji efektivitas Ekstrak Aloevera Terhadap Pertumbuhan Escherichia coli secara in vitro. Jurnal Kesehatan Andalas $6(3)$

Wiyanto, D.B. 2010. Uji Aktivitas Antibakteri Ekstrak Rumput Laut Kappaphycus alvareizi dan Euchema denticullaxa Terhadap Bakteri Aeromonas hydrophila dan Vibrio harveyii. Jurnal Kelautan Vol 3. No 1
Yunus., Arisandi, A., Abida, I, W. (2009) Daya Hambat Ekstrak Metanol Rumput Laut (Euchema spinosum) terhadap Bakteri Aeromonas hydrophila. Jurnal Kelautan: 2 (2): 1622. 